\title{
Traditional Knowledge of Medicinal Plants among Sellers of Jamu Gendong in Wonolopo, Indonesia.
}

\author{
F Husain $^{1}$, B F Wahidah ${ }^{2}$, K B Prasetyo ${ }^{1}$, M A Massholeh ${ }^{1}$ \\ ${ }^{1}$ Department of Sociology and Anthropology, Universitas Negeri Semarang ${ }^{2}$ Department of \\ Biology, UIN Walisongo Semarang \\ \{fadlyhusain@mail.unnes.ac.id ${ }^{1}$, baiqfarhatulwahidah@walisongo.ac.id ${ }^{2}$, mrbayu@mail.unnes.ac.id ${ }^{1}$, \\ gmxm.massh0leh@gmail.com $\left.{ }^{1}\right\}$
}

\begin{abstract}
This study focuses on knowledge of medicinal plants that are used as raw materials by the sellers of jamu gendong. In addition, this study explores the types of jamu that are produced from those medicinal plants. The qualitative method was applied in this research because it can reveal the phenomenon of informants' knowledge and experiences especially concerning on medicinal plants utilization in producing jamu gendong. The research was conducted in Wonolopo Village, Mijen, Semarang, in 2018. There were 20 jamu gendong sellers volunteered in this study. There are 26 species of medicinal plants and 16 plant families are usually used as raw material in making jamu gendong.
\end{abstract}

Keywords: Jamu, Medicinal Plant, Semarang, Traditional Knowledge

\section{INTRODUCTION}

Indonesia is one of the mega biodiversity countries that has around 20,000 plant species [1] There are about 1,180 species of plants have the potential to be medicine [2]. However, only about 300 species have been used for traditional medicine [3].

Plants are known to be a significant source of medicines used in the treatment of various categories of human diseases. Historically all medicinal preparations originating from plants, whether in simple forms of plant parts or in more complex forms of raw, mixed extracts. At present, a large number of drugs are developed from plants that are active against a number of diseases [4]-[8].

The utilization of plants as raw material for medicines has been carried out by humans since the process of concocting. Even though modern medicine has developed to remote areas, the use of plants as medicine is still in demand by the public. The use of this medicinal plant is believed by people because it has relatively small side effects and is cheaper compared to conventional drugs [9], [10]. Traditional medicine has enormous potential benefits in the development of public health. Medicinal plants have been used for centuries by the Indonesian people as traditional medicine which is usually in the form of herbs.

This research is an ethnobotanical study which aims to reveal local knowledge related to medicinal plants owned by the community. This is very important because the ignorance of the potential of medicinal plants could trigger the loss of natural resources that have an impact on decreasing biodiversity. 
As known that the tradition of treatment of a society is inseparable from the connection of local culture. Perceptions about the concept of sickness, health, and the diversity of medicinal plant species are formed through a process of socialization which is inherently trusted and believed to be present [11], [12]. Community in a particular area must have a way of maintaining their health or maintaining their quality of life, which they obtain from generation to generation. The use of medicinal plants as ingredients of traditional medicine is also implemented in quite diverse ways. Treatment of certain diseases can be done differently or with different plants and different rituals [13]. The formulation of the problem of this research are: what types of plants species used in jamu as herbal drinks, what types of jamu are produced by the herbalists.

\section{RESEARCH METHOD}

The research method applied in this research project is qualitative. This research was conducted in Sumbersari Hamlet, Wonolopo Village, Mijen District, Semarang City. The research location is one of the thematic villages (kampung jamu) that raises the theme of jamu as its uniqueness for tourism purposes. Some residents in this hamlet work as sellers of jamu. The study conducted between March-October 2018.

The focus of the study is about the knowledge of medicinal plants that are used as ingredients of herbs and plant parts used. In addition to this matter, this study explores herbal products produced in each production, manufacturing process, and how to obtain the herbal ingredients. The informants were the sellers of jamu gendong as members of the herbal medicine group.

\section{RESULT AND DISCUSSION}

\subsection{Overview of research site}

Wonolopo Village is one of the urban villages that is included in the administrative area of Mijen District, Semarang City. This village is a division of the Mijen Urban Village. Mijen Subdistrict currently administers 14 urban villages. From the geographical side, Wonolopo Village shares regional boundaries with four villages, namely Mijen Village on the east side, Jatisari Village on the south side, Wonoplumbon Village in the west and Ngadirgo Village on the north.

This hamlet is known as Kampung Jamu because of the 115 heads of families who live in this area nearly 40 percent of the residents work as sellers of jamu. The profession has been occupied by people from generation to generation from their ancestors. The profession as a jamu gendong seller has become the primary source of peoples' income.

\subsection{Medicinal plants used for jamu}

Producers and sellers of jamu in Sumbersari hamlet have the knowledge of various kinds of plants that are used in making jamu. There are 26 species of plants that are commonly used to concoct herbs. The following is a list of names of plants commonly used as herbal ingredients based on scientific names of uses and parts of plants used: 
Table 1. Names of medicinal plant

\begin{tabular}{|c|c|c|c|c|c|}
\hline No. & $\begin{array}{l}\text { Vernacular } \\
\text { name }\end{array}$ & $\begin{array}{l}\text { Scientific } \\
\text { name of } \\
\text { species } \\
\end{array}$ & Family & Use & Parts \\
\hline & & & & \multicolumn{2}{|l|}{ - } \\
\hline 1 & Kencur & $\begin{array}{l}\text { Kaempferia } \\
\text { galanga }\end{array}$ & Zingeiberaceae & $\begin{array}{l}\text { - Treating } \\
\text { cough } \\
\text { - Treating sore } \\
\text { throat }\end{array}$ & Rhizome \\
\hline 2 & $\begin{array}{l}\text { Kunir } \\
\text { (Kunyit) }\end{array}$ & $\begin{array}{l}\text { Curcuma } \\
\text { domestica } \\
\text { Vahl. }\end{array}$ & Zingeiberaceae & $\begin{array}{l}\text { - Antibiotic } \\
\text { - Menstruation } \\
\text { - Strengthen } \\
\text { bones } \\
\text { - Wound } \\
\text { healing } \\
\text { - Abdominal } \\
\text { pain }\end{array}$ & Rhizome \\
\hline 3 & Temulawak & $\begin{array}{l}\text { Curcuma } \\
\text { xanthorrihiza } \\
\text { Roxb. }\end{array}$ & Zingeiberaceae & $\begin{array}{l}\text { - Healthy liver } \\
\text { - Strengthen } \\
\text { teeth } \\
\text { - Treating } \\
\text { typhus } \\
\text { - Increasing } \\
\text { appetite }\end{array}$ & Rhizome \\
\hline 4 & $\begin{array}{l}\text { Jahe emprit } \\
\text { (Jahe putih } \\
\text { kecil) }\end{array}$ & $\begin{array}{l}\text { Zingiber } \\
\text { officinale }\end{array}$ & Zingeiberaceae & $\begin{array}{l}\text { - Warms the } \\
\text { body } \\
\text { - Treating } \\
\text { flatulence }\end{array}$ & Rhizome \\
\hline 5 & Sirih & Piper betle L. & Piperacaeae & $\begin{array}{l}\text { - Cleanse } \\
\text { vaginal } \\
\text { discharge } \\
\text { - Antiseptic } \\
\text { - Strengthen } \\
\text { teeth } \\
\text { - Healthy eyes } \\
\text { - Eliminate } \\
\text { body odor } \\
\text { - Woman's } \\
\text { skin } \\
\text { rejuvenation }\end{array}$ & Leaf \\
\hline 6 & $\begin{array}{l}\text { Asem } \\
\text { (Asem } \\
\text { jawa) }\end{array}$ & $\begin{array}{l}\text { Tamarindus } \\
\text { indica }\end{array}$ & Fabaceae & $\begin{array}{l}\text { - Treating } \\
\text { cough } \\
\text { - Reduces } \\
\text { excessive } \\
\text { appetite }\end{array}$ & Fruit \\
\hline 7 & Sambiloto & $\begin{array}{l}\text { Andrographis } \\
\text { paniculata } \\
\text { Ness. }\end{array}$ & Acanthaeceae & $\begin{array}{l}\text { - Treat itching } \\
\text { - Blood } \\
\text { circulation }\end{array}$ & Leaf \\
\hline
\end{tabular}


- Treat

allergies

- Prevent

diabetes

- Overcoming

hypertension

8 Cabe Piper Piperacaeae - Add the

Ceplik retrofractum

essence of Buah

jamu

9 Kates Carica Caricaceae - Dengue fever

papaya - Mother's

breast milk

- Diabetes

- Increase

Leaf

appetite

- Overcoming

constipation

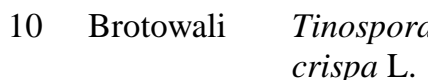

Menispermaceae

- Treating

diabetes

- Treating

Stem

hypertension

11 Lempuyang Zingiber zerumbet

Zingeiberaceae

- Overcoming tired bodies

Rhizome

Smith.

12 Beras

Oryza sativa

Graminae Foeniculum

Apiceae

Fruit/seed

- Adds spicy

flavor

Fruit/seed

14 Kayu

Cinnamomum Lauraceae

- Removes

belly fat

- Lower blood sugar/diabetes

- Adds

delicious

aroma

15 Manjakani Quercus

Fagaceae

- Increase stamina, uterine muscles

Gall

- Tighten

16 Kayu Rapet Paramecia

laevigata

Apocynaceae

Woman's

organs

17 Kunir Putih Curcuma

zedoaria

Zingeiberaceae

- Treat and

Rosce.

cancer

Stem

bark

- Treating cysts

18 Temu

Curcuma

Zingeiberaceae

- Treat uterine

cancer

Rhizome

(kunyit)

Mangga 


\begin{tabular}{|c|c|c|c|c|c|}
\hline 19 & Sirsak & $\begin{array}{l}\text { Annona } \\
\text { muricata L. }\end{array}$ & Annonacaea & $\begin{array}{l}\text { - Lowers } \\
\text { cholesterol } \\
\text { - Overcoming } \\
\text { gout }\end{array}$ & Leaf \\
\hline 20 & $\begin{array}{l}\text { Luntas } \\
\text { (beluntas) }\end{array}$ & $\begin{array}{l}\text { Pluchea } \\
\text { indica Less }\end{array}$ & Asteraceae & $\begin{array}{l}\text { - Mother's } \\
\text { breast Milk }\end{array}$ & Leaf \\
\hline 21 & Dadap & $\begin{array}{l}\text { Erythrina } \\
\text { variegata }\end{array}$ & Fabaceae & $\begin{array}{l}\text { - Complete the } \\
\text { efficacy of } \\
\text { jamu }\end{array}$ & Leaf \\
\hline 22 & Jambu & $\begin{array}{l}\text { Psidium } \\
\text { guajava Linn }\end{array}$ & Mytrtaceae & $\begin{array}{l}\text { - Treating } \\
\text { diarrhea }\end{array}$ & Leaf \\
\hline 23 & Salam & $\begin{array}{l}\text { Syzygium } \\
\text { Polyanthum }\end{array}$ & Mytrtaceae & $\begin{array}{l}\text { - Overcoming } \\
\text { hypertension } \\
\text { - Lowers } \\
\text { cholesterol }\end{array}$ & Leaf \\
\hline 24 & Sere (serai) & $\begin{array}{l}\text { Cymbopogan } \\
\text { citares }\end{array}$ & Poaceae & $\begin{array}{l}\text { - Add herbal } \\
\text { flavor }\end{array}$ & Leaf \\
\hline 25 & Jeruk Nipis & $\begin{array}{l}\text { Citurus } \\
\text { aurantifolia }\end{array}$ & Rutceae & $\begin{array}{l}\text { - Add herbal } \\
\text { flavor }\end{array}$ & Fruit \\
\hline 26 & Mahoni & $\begin{array}{l}\text { Swietenia } \\
\text { macrphylla }\end{array}$ & Meliaceae & $\begin{array}{c}\text { - Treating } \\
\text { diabetes }\end{array}$ & Fruit/seed \\
\hline
\end{tabular}

In addition, there are some additional herbal ingredients or products from plants such as sugar from palm trees (Arenga pinnata) and sugar taken from Saccharum.

\subsection{Types of jamu}

Generally, there are 9 types of jamu where the herbal ingredients have their respective properties. The list of jamu tipes below explains the plant species used in jamu and their properties.

Table 2. Names of regular jamu

\begin{tabular}{|c|c|c|c|}
\hline No & Name of Jamu & Medicinal plants & Properties \\
\hline 1 & Beras Kencur & $\begin{array}{l}\text { - Beras (Oryza sativa), Kencur } \\
\text { (Kaempferia galangal), Kayu Manis } \\
\text { (Cinnamomum), Jahe Emprit } \\
\text { (Zingiber officinale) } \\
\text { Additional plants: } \\
\text { - Serai (Syzygium Polyanthum), Jeruk } \\
\text { Nipis (Cymbopogan citares) }\end{array}$ & $\begin{array}{l}\text { - Treating colds, } \\
\text { flatulence, coughs, } \\
\text { sore throat, } \\
\text { Increase appetite }\end{array}$ \\
\hline 2 & $\begin{array}{l}\text { Kunir (kunyit) } \\
\text { Asem }\end{array}$ & $\begin{array}{l}\text { - Kunyit (Curcuma domestica), Asam } \\
\text { Jawa (Tamarindus indica) } \\
\text { Additional plants: Kayu manis } \\
\text { (Cinnamomum) }\end{array}$ & $\begin{array}{l}\text { - Launch women's } \\
\text { period, Preventing } \\
\text { ulcers, Reduces } \\
\text { excessive appetite, } \\
\text { Cleanse body skin }\end{array}$ \\
\hline 3 & Gula Asem & Asam Jawa (Tamarindus indica) & $\begin{array}{l}\text { - Refreshes the body, } \\
\text { Suppresses } \\
\text { excessive appetite, }\end{array}$ \\
\hline
\end{tabular}


4 Temulawak

Cabe Puyang

6

Daun Pepaya

$7 \quad$ Sirih

8 Sambiloto

Kunyit Kental
- Temulawak (Curcuma xanthorrihiza), Sambiloto

(Andrographis paniculata Ness), Kunyit (Curcuma domestica)

- Cabe jamu (Capsicum frutescen L), Lempuyang (Zingiber zerumbet Smith), Adas (Foeniculum vulgare)

- Pepaya (Carica papaya), Adas (Foeniculum vulgare)

Additional plants:

- Daun Dadap (Erythrina variegata), Daun Jambu (Psidium guajava Linn)

- Daun Sirih (Piper betle L), Kunyit (Curcuma domestica)

Additional plant:

- Manjakani (Quercus infectoria Gall),

Kunyit Mangga (Curcuma mannga),

Kayu Rapet (Paramecia laevigata),

Daun Beluntas (Pluchea indica Less)

- Sambiloto Andrographis paniculata Ness), Brotowali (Tinospora crispa L), Temulawak Curcuma xanthorrihiza)

Additional plants:

- Mahoni (Swietenia macrphylla)

- Kunyit (Curcuma domestica)
Treat coughs, Treating canker sores

- Increase appetite, Healthy liver, Prevent ulcers, Strengthen teeth, Promotes metabolism, Treating typhus, Prevent the growth of cancer cells

- Overcoming tired and achy body

- Treating diabetes, Increase appetite, Increase blood platelets, Treating dengue fever, Launches mother's breast milk, Defecation, Treat flatulence

- Overcoming body odor, Treating vaginal discharge in women,

Cleaning the skin, Increasing stamina, Antiseptic, Eyes, Strengthen teeth, Treating canker sores, Treating cysts, Preventing acne

- Treat itching, Blood circulation, Prevent from diabetes, Treat allergies, Treating hypertension - Treat abdominal pain, Antibiotics, Wound healing, Strengthens bones 
Furthermore, there are also other types of jamu which are formulated by the seller according to the customer's request. This customer demand usually refers to the treatment of certain illnesses or only to maintain fitness and health of the body. The types of herbal medicine are jamu kunyit putih ((Curcuma zedoaria Rosce.), daun sirsak (Annona muricata L), kencur jahe, (Zingiber officinale and Kaempferia galanga) and daun salam (Citurus aurantifolia).

\section{CONCLUSIONS}

The producers/sellers of herbal drink of jamu gendong in Wonolopo Semarang have traditional knowledge of medicinal plants as ingredients in decoction of jamu gendong. There are 26 species of medicinal plants and 16 plant families are usually used as raw material in making jamu gendong. Some parts of species are mixed and made into nine types of regular or common jamu gendong. However, the rest of species are used into special herbal drinks or base on consumers request.

\section{REFERENCES}

[1] C. Kusmana and A. Hikmat, "Keanekaragaman hayati flora di Indonesia," J. Pengelolaan Sumberd. Alam dan Lingkung., vol. 2, no. 2, pp. 187-198, 2015.

[2] E. Widjaja et al., The Current Biodiversity of Indonesia 2014. Kekinian Keanekaragaman Hayati Indonesia 2014. Jakarta: LIPI Press, 2014.

[3] A. Hariana, Tumbuhan Obat dan Khasiatnya. Jakarta: Penebar Swadaya, 2004.

[4] G. Chekole, "Ethnobotanical study of medicinal plants used against human ailments in Gubalafto District, Northern Ethiopia," J Ethnobiol Ethnomed., vol. 13, p. 55, Oct. 2017.

[5] M. Heinrich and S. Gibbons, "Ethnopharmacology in drug discovery: an analysis of its role and potential contribution," J Pharm Pharmacol., vol. 53, no. 4, pp. 425-432, Feb. 2010.

[6] S. Jain, P. Yadav, V. Gill, N. Vasudeva, and N. Singla, "Terminalia arjuna a sacred medicinal plant: phytochemical and pharmacological profile," Phytochem Rev., vol. 8, no. 2, pp. 491-502, 2009.

[7] B. Petrovska, "Historical review of medicinal plants' usage," Pharmacogn Rev., vol. 6, no. 11, pp. 1-5, Nov. 2012.

[8] L. Shosan, O. Fawibe, A. Ajiboye, T. Abeegunrin, and D. Agboola, "Ethnobotanical Survey of Medicinal Plants Used in Curing Some Diseases in Infants in Abeokuta South Local Government Area of Ogun State, Nigeria," Am J Plant Sci, vol. 5, pp. 3258-3268, 2014.

[9] L. M. Gupta and R. Raina, "Side effects of some medicinal plants," Curr Sci., vol. 75, no. 9, pp. 897-900, 1998.

[10] L. Sari, "Pemanfaatan Obat Tradisional dengan Pertimbangan Manfaat dan Keamanannya," Pharm. Sci. Res. (PSR); Vol 3, No 1, Aug. 2012.

[11] T. Ceolin, R. M. Heck, R. L. Barbieri, E. Schwartz, R. M. Muniz, and C. N. Pillon, "Plantas medicinais: transmissão do conhecimento nas famílias de agricultores de base ecológica no Sul do RS," Rev Esc Enferm., vol. 45. scielo, pp. 47-54, 2011.

[12] S. Mathez-Stiefel and I. Vanderbroek, "Distribution and transmission of medicinal plant knowledge in the andean highlands: a case study from Peru and Bolivia," J Evid Based Complement. Altern Med., vol. 2012, p. 18 pages, 2012.

[13] C. Desmarchelier, A. Gurni, G. Ciccia, and A. M. Giulietti, "Ritual and medicinal plants 
of the Ese'ejas of the Amazonian rainforest (Madre de Dios, Perú)," J Ethnopharmacol., vol. 52, no. 1 , pp. 45-51, 1996. 